\title{
Erwinia pyrifoliae sp. nov., a novel pathogen that affects Asian pear trees (Pyrus pyrifolia Nakai)
}

\author{
Won-Sik Kim, ${ }^{1}$ Louis Gardan, ${ }^{2}$ Seong-Lyul Rhim ${ }^{3}$ and Klaus Geider ${ }^{1}$
}

\footnotetext{
1 Max-Planck-Institut für Zellbiologie, Rosenhof, D-68526 Ladenburg, Germany

2 INRA, Pathologie Végétale et Phytobactériologie, 42, rue Georges Morel, F-49071 Beaucouzé, Cedex, France

3 Department of Genetical Engineering, College of Natural Science, Hallym University, 1 OkcheonDong, Chuncheon-Si, Kangwon-Do, 200-702, South Korea
}

\author{
Author for correspondence: Klaus Geider. Tel: +496203 106 117. Fax: +496203106122. \\ e-mail: kgeider@zellbio.mpg.de
}

\begin{abstract}
A novel pathogen from Asian pears (Pyrus pyrifolia Nakai) was analysed by sequencing the $16 \mathrm{~S}$ rDNA and the adjacent intergenic region, and the data were compared to related Enterobacteriaceae. The 16S rDNA of the Asian pear pathogen was almost identical with the sequence of Erwinia amylovora, in contrast to the 16S-23S rRNA intergenic transcribed spacer region of both species. A dendrogram was deduced from determined sequences of the spacer regions including those of several related species such as Erwinia amylovora, Enterobacter pyrinus, Pantoea stewartii subsp. stewartii and Escherichia coli. Dendrograms derived from 121 biochemical characteristics including Biotype 100 data placed the Asian pear pathogen close to Erwinia amylovora and more distantly to other members of the species Erwinia and to the species Pantoea and Enterobacter. Another DNA relatedness study was performed by DNA hybridizations and estimation of $\Delta T_{m}$ values. The Asian pear strains constituted a tight DNA hybridization group (89-100\%) and were barely related to strains of Erwinia amylovora (40-50\%) with a $\Delta T_{m}$ in the range of 5.2-6.8. The G+C content of DNA from the novel pathogen is 52 mol\%. Therefore, it is proposed that strains isolated from Asian pears constitute a new species and the name Erwinia pyrifoliae is suggested; the type strain is strain Ep16/96 ${ }^{\top}$ ( $=$ CFBP $^{4172}{ }^{\top}$ = DSM 12163').
\end{abstract}

\section{Keywords: Erwinia pyrifoliae, taxonomy, DNA-DNA hybridization, rDNA} sequencing

\section{INTRODUCTION}

A recently observed necrotic disease of Asian pear fruit trees (Pyrus pyrifolia cv. 'Shingo' and 'Mansamgil') near Chuncheon in Korea has resulted in isolation and partial characterization of a bacterial pathogen (Rhim et al., 1999). Symptoms on pear trees in the Korean orchards remotely resembled those of fire blight, but microbiological assays and the absence of the PCR signals expected for the presence of Erwinia amylovora distinguished the novel Erwinia sp. from the fire blight pathogen. The new pathogen was also different from the recently described Korean pear

\footnotetext{
Abbreviations: ITS, intergenic transcribed spacer region; RCS, reducing compounds from sucrose.

The EMBL accession number for the 16S rRNA sequence of Erwinia pyrifoliae strain Ep1/96 is AJ009930.
}

pathogen Enterobacter pyrinus (Chung et al., 1993) especially by its lack of nitrate reduction and for growth at high temperature, as well as acid production in the presence of aesculin or cellobiose (Rhim et al., 1999).

The purpose of this work was the differentiation of the novel pathogen from Erwinia amylovora, Pantoea and Enterobacter by using DNA sequence analysis of the $16 \mathrm{~S}$ rDNA and the adjacent intergenic transcribed spacer region, by numerical analysis of phenotypical characteristics, DNA-DNA hybridization and the $\mathrm{G}+\mathrm{C}$ content. Our findings resulted in the description of a new species: Erwinia pyrifoliae.

\section{METHODS}

Strains. The strains investigated in the experiments and used for differentiation are listed in Tables 1 and 2. They were used under authorities mentioned in Young et al. (1996). We 
Table 1. Strains used for molecular characterization of Erwinia pyrifoliae

\begin{tabular}{|c|c|c|c|}
\hline Strain & No. in collection* & Plant, origin, year of isolation & Reference/source \\
\hline \multicolumn{4}{|c|}{ Erwinia amylovora } \\
\hline $\mathrm{Ea} 1 / 79$ & & $\begin{array}{l}\text { Cotoneaster sp., Germany, } 1979 \text { (obtained from } \\
\text { W. Zeller) }\end{array}$ & Falkenstein et al., 1988 \\
\hline \multicolumn{4}{|c|}{ Enterobacter pyrinus } \\
\hline $90.2^{\mathrm{T}}$ & $\mathrm{KCTC} 2520^{\mathrm{T}}$ & $\begin{array}{l}\text { Pyrus pyrifolia, South Korea (from Korean strain } \\
\text { collection) }\end{array}$ & Chung et al., 1993 \\
\hline \multicolumn{4}{|c|}{ Erwinia pyrifoliae } \\
\hline Ep8/95 & DSM 12393 & Pyrus pyrifolia, South Korea, 1995 & S.-L. Rhim, unpublished \\
\hline Ep1/96 & $\begin{array}{l}\text { CFBP } 4171 \\
\text { DSM } 12162\end{array}$ & Pyrus pyrifolia, South Korea, 1996 & S.-L. Rhim, unpublished \\
\hline Ep16/96 & $\begin{array}{l}\text { CFBP } 4172^{\mathrm{T}} \\
\text { DSM } 12163^{\mathrm{T}}\end{array}$ & Pyrus pyrifolia, South Korea, 1996 & S.-L. Rhim, unpublished \\
\hline Ep28/96 & CFBP 4173 & Pyrus pyrifolia, South Korea, 1996 & S.-L. Rhim, unpublished \\
\hline Ep31/96 & CFBP 4174 & Pyrus pyrifolia, South Korea, 1996 & S.-L. Rhim, unpublished \\
\hline Ep4/97 & DSM 12394 & Pyrus pyrifolia, South Korea, 1997 & $\begin{array}{l}\text { S.-L. Rhim \& K. Geider, } \\
\text { unpublished }\end{array}$ \\
\hline Ep102/98 & & Pyrus pyrifolia, South Korea, 1998 & S.-L. Rhim, unpublished \\
\hline
\end{tabular}

* CFBP, Collection Française des Bactéries Phytopathogènes; DSM, DSMZ-Deutsche Sammlung von Mikroorganismen und Zellkulturen; KCTC, Korean Collection of Type Cultures.

assayed four strains isolated from Pyrus pyrifolia, the type strain of Erwinia amylovora, and 20 type strains of phytopathogenic and saprophytic Erwinia, Pantoea and Enterobacter $\mathrm{sp}$. for constructing a dendrogram.

Nucleotide sequencing. The $16 \mathrm{~S}$ rRNA genes and the 16S-23S rRNA intergenic transcribed spacer region (ITS) were cloned with consensus primers into vector pGEM-T (Promega) and pBluescript KS, respectively. The primers for PCR amplification were for 16S rDNA fd2 ( $5^{\prime}$ AGA GTT TGA TCA TGG CTC AG) and rP1 (5' ACG GTT ACC TTG TTA CGA CTT) (Weisburg et al., 1991) and for the ITS PIGL (5' GCG CGC GTCGAC ACC TGC GGT TGG AAC ACC) and PIGR (5' GCG CGC TCTAGA CAC CGT GTA CGC TTA GTC). They were synthesized with Beckman Oligo 1000M DNA Synthesizer. PCR cloning of ITS was done with $p f u$ DNA polymerase and primers with $S a l I$ and $X b a I$ restriction sites (underlined) and three GC oligonucleotide pairs. PCR was performed in $50 \mathrm{ml}$ containing $30 \mathrm{pmol}$ each primer, $3 \mathrm{U}$ cloned pfu DNA polymerase (Stratagene), $10 \mathrm{ng}$ isolated DNA or 10000 cells, and $20 \mathrm{mM}$ dATP, dCTP, dGTP and dTTP (Boehringer Mannheim) in the $10 \times$ buffer provided by Stratagene. Amplification was carried out in an Eppendorf mastercycler 5330 in 30 cycles. Denaturation was done at $94{ }^{\circ} \mathrm{C}$ (in the first cycle for $45 \mathrm{~s}$ and in subsequent cycle for $30 \mathrm{~s}$ ) and $45 \mathrm{~s}$ at $52^{\circ} \mathrm{C}$ for annealing followed by $2 \mathrm{~min}$ at $72^{\circ} \mathrm{C}$ for polymerization. For cloning, the PCR product was eluted from a $1.0 \%$ ultrapure agarose gel, digested with $S a l I$ and $X b a I$ and ligated into the vector pBluescript KS. The insertions were repeatedly sequenced with an automatic sequencer (ALF; Pharmacia).

Biochemical and physiological tests. Assimilation of 99 carbohydrates, organic acids and amino acids was studied using Biotype 100 strips (bioMérieux) which were incubated at $28^{\circ} \mathrm{C}$; the growth was recorded after 4 and $6 \mathrm{~d}$ incubation. Twenty-two additional tests were also performed. Acid production from lactose, methyl $\alpha$-glucoside, melibiose, $\mathrm{D}(+)$-arabitol, sorbitol, $\mathrm{D}(-)$-arabinose, mannitol, raffinose, $\mathrm{D}(-)$-tartrate and utilization of malonate were tested on the basal medium of Ayers et al. (1919) supplemented with $0.1 \%(\mathrm{w} / \mathrm{v})$ of carbohydrates and organic acid sodium salts. The other tests were classical techniques (Smibert \& Krieg, 1981; Lelliott \& Stead, 1987; Schroth \& Hildebrand, 1988) and included: Simmons citrate, gelatin hydrolysis, lecithinase, casein hydrolysis, indole production, arginine dihydrolase (Møller), reducing compounds from sucrose (RCS), growth on $\mathrm{NaCl}(5 \%$ w/v), growth at $36^{\circ} \mathrm{C} / 39^{\circ} \mathrm{C}$ in liquid King's B, liquefaction of calcium polygalacturonate in Sutton medium and utilization of inulin.

Numerical taxonomy. A total of 121 characteristics were included in the numerical taxonomy analysis. The matrix of distances was calculated by using the Jaccard coefficient (Sneath \& Sokal, 1973) and cluster analysis was done with the unweighted pair group method with averages (UPGMA) (Sneath \& Sokal, 1973). ITS sequence were aligned with the program ALIGN version 2.0 (Scientific \& Educational Software) using a mismatch penalty of 2 , an open gap penalty of 4 and an extend gap penalty of 1 . Phylogenetic interferences were derived from multiple alignments of the ITS region using programs CLUSTREE and CLUSTAL $w$ with the neighbour-joining method of Saitou \& Nei (1987).

DNA-DNA hybridization and thermal stability. Extraction and purification of DNA were performed with previously described methods (Brenner et al., 1982). Native DNAs were labelled in vitro by using the Megaprime DNA-labelling system (Amersham International). DNA-DNA hybridization experiments were done with labelled DNA from Erwinia pyrifoliae Ep16/96 ${ }^{\mathrm{T}}\left(\mathrm{CFBP} 4172^{\mathrm{T}}\right)$ at a temperature of $65^{\circ} \mathrm{C}$ for reassociation. The S1 nucleaseTCA method was used for hybridization (Brenner et al., 1982; Crosa et al., 1973).

The temperature at which $50 \%$ of reassociated DNA became hydrolysable by enzyme $\mathrm{S}_{1}\left(T_{\mathrm{m}}\right)$ was determined by the method of Crosa et al. (1973). The $\Delta T_{\mathrm{m}}$ is the difference 
between the $T_{\mathrm{m}}$ of the homoduplex and the $T_{\mathrm{m}}$ of the heteroduplex.

DNA base composition. The $\mathrm{G}+\mathrm{C}$ content of Erwinia pyrifoliae CFBP $4172^{\mathrm{T}}$ was determined by a thermal denaturation temperature method (Marmur \& Doty, 1962) and was calculated with the equation of Owen \& Lapage (1976).

\section{RESULTS}

\section{Characterization of Erwinia pyrifoliae by sequencing of the 165 rDNA and the adjacent ITS}

Analogous to characterization of the 16S rDNA sequence of Erwinia amylovora (Bereswill et al., 1995), we amplified the corresponding sequence of Erwinia pyrifoliae with consensus primers. Cleavage of the amplification product with restriction enzyme HaeIII produced identical DNA fragments for both organisms, but different fragments in comparison to
Enterobacter pyrinus and Pantoea stewartii subsp. stewartii (data not shown). To further analyse the $16 \mathrm{~S}$ rDNA sequences of Erwinia pyrifoliae, Enterobacter pyrinus and Pantoea stewartii subsp. stewartii on the nucleotide level, the amplified fragments were cloned into vector pGEM-T. The $16 \mathrm{~S}$ rDNA of Erwinia amylovora was previously sequenced (Bereswill et al., 1995; Kwon et al., 1997), but for confirmation the $1.4 \mathrm{~kb}$ DNA fragment was cloned again from strain Ea1/79, and sequenced several times to confirm the corrected nucleotide sequence. When the 16S rDNA sequence of Ep1/96 and those of related bacteria were compared, the Erwinia pyrifoliae sequence was more than $99 \%$ homologous to Erwinia amylovora Ea1/79 and $97 \%$ homologous to Pantoea stewartii subsp. stewartii DC283 and decreased for other erwiniae (Table 2). This correlation of identical residues assigned Erwinia pyrifoliae to be closely related to Erwinia amylovora, but more distinct from Enterobacter pyrinus and Pantoea stewartii subsp. stewartii.

Table 2. Differences in the 165 rRNA nucleotide sequence of several bacterial species in comparison to Erwinia pyrifoliae

${ }^{\mathrm{T}}$ type strain; ATCC, American Type Culture Collection; DSM, DSMZ-Deutsche Sammlung von Mikroorganismen und Zellkulturen; KCTC, Korean Collection of Type Cultures; LMG, Laboratorium voor Microbiologie, Gent.

\begin{tabular}{|c|c|c|c|c|c|}
\hline Species & Strain & EMBL no. & $\begin{array}{l}\text { Length } \\
\text { (bp) }\end{array}$ & $\begin{array}{l}\text { Homology } \\
(\%)\end{array}$ & $\begin{array}{l}\text { Non-matching } \\
\text { nucleotides }\end{array}$ \\
\hline Erwinia pyrifoliae & Ep1/96 & AJ009930 & 1435 & 100 & 0 \\
\hline Erwinia amylovora & $\mathrm{Ea} 1 / 79$ & AJ010485 & 1437 & 99 & 8 \\
\hline Erwinia amylovora & ATCC $15580^{T}$ & U80195 & 1439 & 99 & 12 \\
\hline Erwinia persicina & LMG 2691 & AJ001190 & 1440 & 98 & 38 \\
\hline Erwinia rhapontici & LMG 2688 & Z96087 & 1439 & 97 & 42 \\
\hline Pantoea stewartii subsp. stewartii* & DC283† & Unpublished & 1439 & 97 & 45 \\
\hline Erwinia psidii & LMG 7034 & Z96085 & 1438 & 97 & 53 \\
\hline Pantoea ananatis pv. ananatis & ATCC $33244^{\mathrm{T}}$ & U80196 & 1438 & 97 & 55 \\
\hline Klebsiella pneumoniae & DSM 30104 & X87276 & 1439 & 97 & 56 \\
\hline Pantoea ananatis pv. uredovora & ATCC $19321^{\mathrm{T}}$ & U80209 & 1438 & 97 & 57 \\
\hline Pantoea agglomerans & ATCC $33243^{\mathrm{T}}$ & U80202 & 1437 & 97 & 58 \\
\hline Escherichia coli & $\mathrm{K}-12$ & J01695 & 1440 & 97 & 58 \\
\hline Erwinia mallotivora & LMG 2708 & Z96084 & 1431 & 96 & 59 \\
\hline $\begin{array}{l}\text { Pectobacterium carotovorum subsp. } \\
\text { carotovorum } \S\end{array}$ & ATCC $15713^{\mathrm{T}}$ & U80197 & 1440 & 96 & 63 \\
\hline $\begin{array}{l}\text { Pectobacterium carotovorum subsp. } \\
\text { betavasculorum } \|\end{array}$ & ATCC $43762^{\mathrm{T}}$ & U80198 & 1441 & 96 & 65 \\
\hline Erwinia chrysanthemi & ATCC $11663^{\mathrm{T}}$ & U80200 & 1441 & 96 & 68 \\
\hline Enterobacter pyrinus & KCTC $2520^{\mathrm{T}}$ & AJ010486 & 1439 & 96 & 72 \\
\hline Erwinia tracheiphila & LMG $2906^{\mathrm{T}}$ & Y13250 & 1428 & 94 & 89 \\
\hline Brenneria salicis & ATCC $15721^{\mathrm{T}}$ & U80210 & 1438 & 94 & 91 \\
\hline
\end{tabular}

* Previous name: Erwinia stewartii.

$\div \mathrm{Nal}^{\mathrm{r}}$ mutant of SS104 (Z05, Dye's isolate; related to the type strain SS11, Dye's isolate Z010, ATCC 8199 ${ }^{\mathrm{T}}$ ).

$\$$ Previous name: Erwinia herbicola.

$\S$ Previous name: Erwinia carotovora subsp. carotovora.

|| Previous name: Erwinia carotovora subsp. betavasculorum.

T Previous name: Erwinia salicis. 


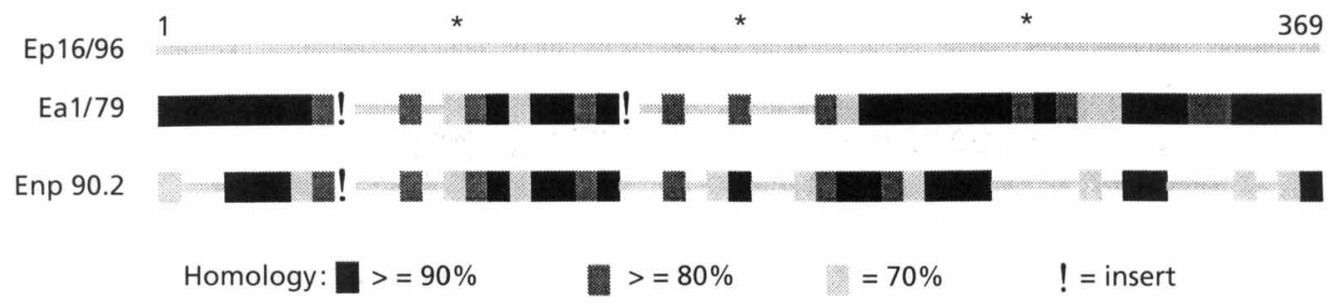

Identity: narrow bars in rows 2 and 3

Fig. 1. Scheme aligning the $16 \mathrm{~S}-235$ spacer region from Erwinia pyrifoliae (Ep1/96; EMBL accession no. AJ009930), Erwinia amylovora (Ea1/79; AJ010485) and Enterobacter pyrinus (Enp90. $2^{\top}$; AJ010486). The Glu-tRNA gene is marked. A similar profile was obtained in the alignment of the related nucleotide sequence from the ITS of strain Ep16/96 (AJ132969).

Additional nucleotide sequences were obtained from published data, which were also used for comparison with the 16S rDNA of Erwinia pyrifoliae. A gradient of relatedness is shown in Table 2 based on the number of nucleotide differences.

\section{Comparison of the intergenic regions}

We have also investigated the DNA sequence of the 16S rDNA-23S rDNA intergenic transcribed spacer (ITS) region. This sequence is more variable among bacteria and has widely been used for differentiation (Zavaleta et al., 1996). The consensus primers PIGL and PIGR were used to amplify the intergenic region from Erwinia pyrifoliae strain Ep1/96, Erwinia amylovora strain Ea1/79, Enterobacter pyrinus strain $90.2^{\mathrm{T}}$, Pantoea stewartii subsp. stewartii strain DC283 and the Escherichia coli $\mathrm{K}-12$ strain DH5 $\alpha$. The DNA sequences of these organisms were significantly divergent, not only between Erwinia pyrifoliae, Erwinia amylovora and Enterobacter pyrinus (Fig. 1), but also to Pantoea stewartii subsp. stewartii and Escherichia coli with $86,74,81$ and $75 \%$ identical residues, respectively. All ITSs in the sequence alignment showed a single copy of the gene for tRNA ${ }^{\text {Glu }}$. The DNA adjacent to the tRNA ${ }^{\text {Glu }}$ genes of Erwinia pyrifoliae and Erwinia amylovora was most divergent (Fig. 1). When the determined ITS sequences and additional sequences from nucleotide databases were applied to calculate species relatedness, the dendrogram (Fig. 2) showed a remarkable evolutionary distance of Erwinia pyrifoliae and Erwinia amylovora.

Oligonucleotides were designed from the ITS and the 16S rDNA region of Erwinia pyrifoliae, which specifically detected the pathogen extracted from wood samples of Asian pear trees (W.-S. Kim \& K. Geider, unpublished). Strains Ep8/95, isolated in 1995, Ep4/97 (1997) and a series of strains isolated in 1998 (represented by strain Ep102/98) gave rise to a positive signal with these primers in contrast to PCR assays with lysates from other bacteria such as Pseudomonas syringae pv. syringae, Pantoea agglomerans (Erwinia

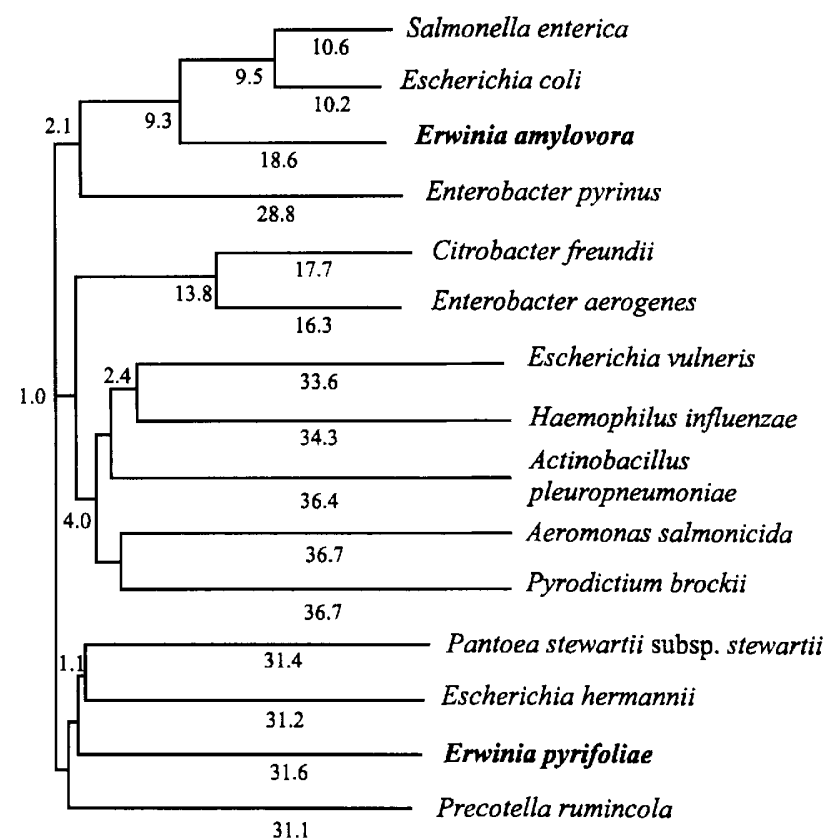

Fig. 2. Dendrogram of Erwinia pyrifoliae and related bacteria based on the 165-235 spacer region. Bootstrap values presented at the nodes were calculated with a frequency of a particular group to appear among 1000 bootstrapping samples. Strains Ep1/96 and Ep16/96 ${ }^{\top}$ were used for the input of nucleotide sequence information.

herbicola) or Erwinia amylovora. Strains Ep8/95 and Ep4/97 were also tested with additional procedures and produced the same responses as found for Erwinia pyrifoliae Ep16/96 ${ }^{\mathrm{T}}$. These investigations confirm the isolation of Erwinia pyrifoliae in four subsequent years from necrotic branches of Pyrus pyrifolia.

\section{Numerical analysis of phenotypic characteristics}

Biotype 100 assays were applied to describe a dendrogram displaying the distance relationships among 25 strains included in this study. At a distance of 0.31 , five phena clustering at least two strains and 10 

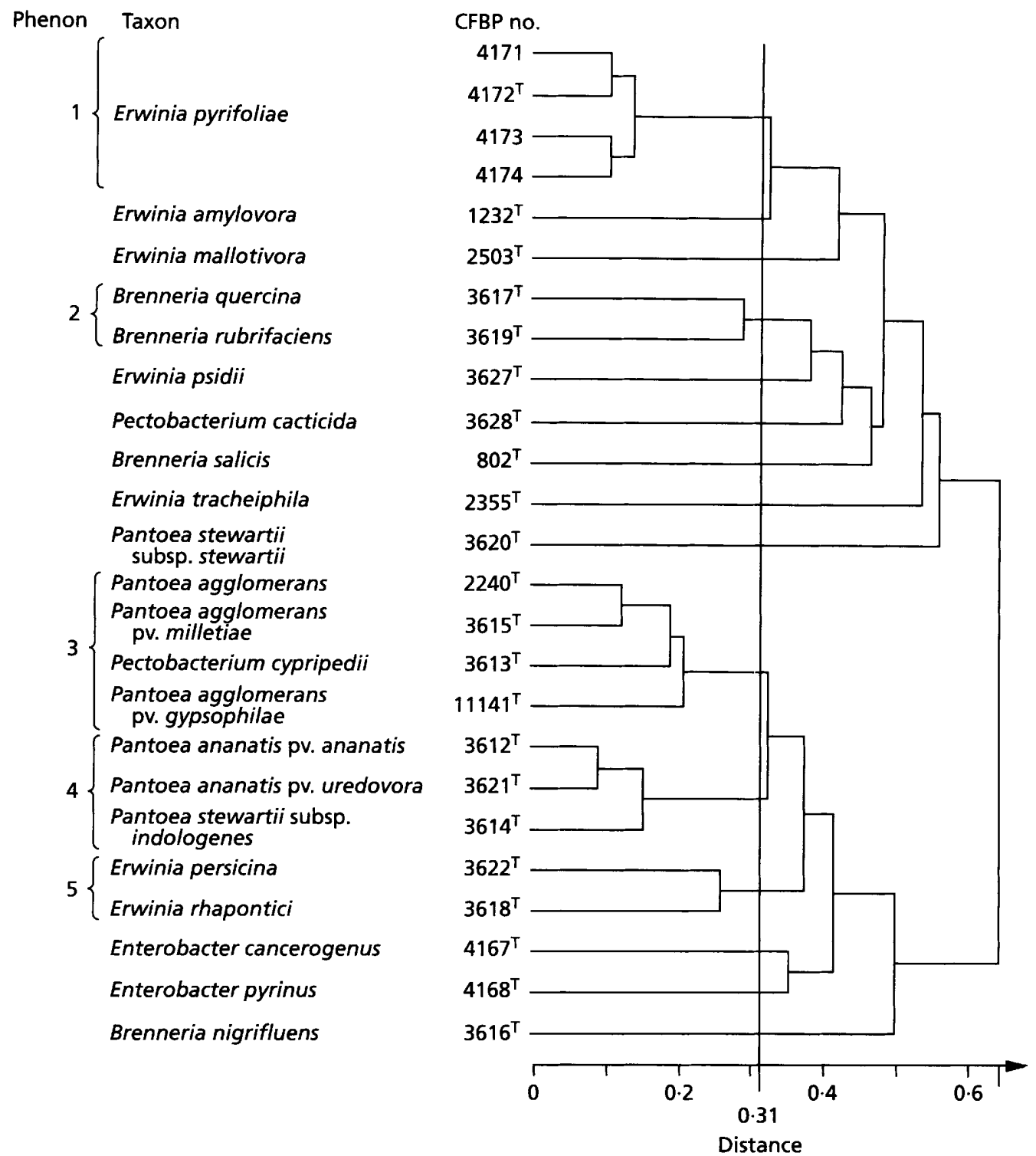

Fig. 3. Dendrogram for Erwinia pyrifoliae strains and Erwinia, Enterobacter and Pantoea type strains. The graph was calculated from data with Biotype 100 strips and 22 additional tests by the unweighted pair group method with averages (UPGMA) of the distances of the Jaccard coefficient. See footnotes to Table 2 concerning recent name changes.

isolated strains were observed. The distribution of strains in the different phena and isolated strains is shown in Fig. 3. Phenon 1, containing the four strains of Erwinia pyrifoliae, is closely related to the type strain CFBP 1232 of Erwinia amylovora and to Erwinia mallotivora. The four other phena contained two to four type strains of phytopathogenic Erwinia, Pantoea and Enterobacter. Biochemical and physiological characteristics that differentiate the five phena and the 10 isolated strains are shown in Table 3. Six tests, i.e. growth in the presence of $\mathrm{L}$-proline, melibiose, gelatinase, $\beta$-gentiobiose, L-glutamate or $\mathrm{L}(+)$-arabinose differentiated Erwinia pyrifoliae from Erwinia amylovora. The 17 biochemical and physiological tests were selected to differentiate the five phena and isolated strains from each other on the basis of at least three characteristics.

\section{DNA base composition and relatedness}

Erwinia pyrifoliae Ep $16 / 96^{\mathrm{T}}\left(\mathrm{CFBP} 4172^{\mathrm{T}}\right.$ ) had a DNA $\mathrm{G}+\mathrm{C}$ content of $52 \mathrm{~mol} \%$, Erwinia amylovora 54 $\mathrm{mol} \%$ and Erwinia mallotivora $50 \mathrm{~mol} \%$. The strains of Erwinia pyrifoliae were $89-100 \%$ related to the strain CFBP $4172^{\mathrm{T}}$. The three strains of Erwinia amylovora including the type strain CFBP 1232 were 40-52\% related to Erwinia pyrifoliae strain CFBP $4172^{\mathrm{T}}$. The $\Delta T_{\mathrm{m}}$ values were in the range of $5 \cdot 2-6 \cdot 8$. Thus, the strains isolated from Pyrus pyrifolia constituted a single DNA hybridization group. 
Table 3. Phenotypic characteristics that differentiate Erwinia pyrifoliae from phena 1, 2, 3, 4, 5 and other bacterial species

Strains assigned to a phenon are given in Fig. 3. 1, Erwinia pyrifoliae; A, Erwinia amylovora; B, Erwinia mallotivora; C, Erwinia psidii; D, Pectobacterium cacticida; E, Erwinia salicis; F, Erwinia tracheiphila; G, Pantoea stewartii subsp. stewartii; H,

Enterobacter cancerogenus; I, Enterobacter pyrinus; J, Brenneria nigrifluens. Values are percentage of positive strains.

\begin{tabular}{|c|c|c|c|c|c|c|c|c|c|c|c|c|c|c|c|}
\hline \multirow[t]{2}{*}{ Character } & \multicolumn{5}{|c|}{ Phenon } & \multicolumn{10}{|c|}{ Other strains } \\
\hline & 1 & 2 & 3 & 4 & 5 & $\mathbf{A}$ & B & C & D & $\mathbf{E}$ & $\mathbf{F}$ & G & $\mathbf{H}$ & I & $\mathbf{J}$ \\
\hline \multicolumn{16}{|c|}{ Growth in presence of: } \\
\hline L-Proline & + & - & + & + & + & - & - & - & - & - & - & - & - & + & + \\
\hline Gelatin & - & - & - & + & - & + & - & + & - & - & - & - & - & - & + \\
\hline$\beta$-Gentiobiose & - & 50 & 25 & + & + & + & - & - & + & - & - & - & + & + & + \\
\hline L-Glutamate & + & + & + & + & + & - & - & + & - & - & - & + & + & + & + \\
\hline L(+)-Arabinose & + & + & + & + & + & - & - & + & - & - & - & + & + & + & + \\
\hline \multicolumn{16}{|l|}{ Utilization of: } \\
\hline Maltotriose & - & - & + & + & + & - & - & - & - & - & - & - & + & + & + \\
\hline$\alpha$-Lactose & - & - & + & + & + & - & - & - & - & - & - & - & + & + & + \\
\hline D-Saccharate & - & - & + & + & - & - & + & + & - & - & + & - & + & + & - \\
\hline RCS & + & + & - & - & - & + & + & - & - & + & + & - & - & - & - \\
\hline $\mathrm{D}(+)$-Xylose & - & - & + & + & - & - & + & - & - & - & - & + & + & - & - \\
\hline Mucate & - & - & + & + & - & - & - & + & - & - & + & - & + & - & - \\
\hline L-Histidine & - & - & + & + & + & - & - & - & - & - & - & - & - & - & + \\
\hline Malonate & - & - & + & - & + & - & - & - & + & - & - & - & + & + & - \\
\hline $\mathrm{D}(+)$-Melibiose & - & - & - & + & + & - & - & - & - & t & - & + & - & - & + \\
\hline $\mathrm{D}(+)$-Raffinose & - & - & - & + & + & - & - & - & - & + & - & + & - & - & + \\
\hline $\mathrm{D}(+)$-Mannose & - & + & + & + & + & - & + & + & + & - & - & + & + & + & + \\
\hline
\end{tabular}

\section{DISCUSSION}

Strains of the Asian pear pathogen Erwinia pyrifoliae are related to each other but distinct from Erwinia amylovora. A high similarity to the fire blight pathogen was based on the 16S rRNA sequences. The sequence of the ITS showed discordance for the two species. This result matches that of Leblond-Bourget et al. (1996), whereby evolutionary divergence of the ITS is much greater than that of $16 \mathrm{~S}$ rRNA. In a sequence comparison of the ITS from eight Erwinia amylovora strains, which were isolated from different geographic origins, all strains showed a complete sequence homology (W.-S. Kim \& K. Geider, unpublished). On the other hand, Erwinia pyrifoliae is quite divergent from Erwinia amylovora in its ITS sequence, including nucleotide changes in the tRNA ${ }^{\text {Glu }}$ ORF. This tRNA gene between the 16S and 23S rRNA has also been used for differentiation (Loughney et al., 1982). All species investigated here had one tRNA ${ }^{\text {Glu }}$ gene. Erwinia pyrifoliae differs in that region from Erwinia amylovora and from Enterobacter pyrinus by one additional and nine different nucleotides (Fig. 1).

This ambiguous relation of Erwinia pyrifoliae and Erwinia amylovora was already observed by the first characterization of the Asian pear pathogen (Rhim et al., 1999). It produces necrotic symptoms resembling fire blight, although the bark tissue is still greenish below the black-brown surface in contrast to the red-brown colour in case of fire blight. Plating on MM2Cu agar (Bereswill et al., 1997) gave a mucoid colony morphology as for Erwinia amylovora, but of a slightly yellow colour. Microbiological assays were overlapping in part or divergent for others. PCR assays with plasmid primers (Bereswill et al., 1992) or from the ams region (Bereswill et al., 1995) were negative for Erwinia pyrifoliae, which lacks the plasmid of $29 \mathrm{~kb}$ common to Erwinia amylovora (Falkenstein $e t$ al., 1988).

Strains isolated from necrotic branches of Pyrus pyrifolia constituted a discrete DNA genomic group (genomospecies) with the type strain Ep16/96 ${ }^{\mathrm{T}}$ (CFBP $4172^{\mathrm{T}}$ ), since they were $89-100 \%$ related to each other. The strains of Erwinia amylovora, including the type strain CFBP 1232, are $40-52 \%$ related to the type strain of Erwinia pyrifoliae with a $\Delta T_{\mathrm{m}}$ above $5^{\circ} \mathrm{C}$ $\left(5 \cdot 2-6 \cdot 8^{\circ} \mathrm{C}\right)$. Presently, the molecular definition of bacterial species is applied to strains which are about $70 \%$ related, with $\Delta T_{\mathrm{m}}$ values that do not exceed $5{ }^{\circ} \mathrm{C}$. Thus, the bacteria associated with necrosis of Asian pear trees (Nashi) are four members of one new species.

A numerical taxonomy study of the Asian pear pathogen was related to 25 phytopathogenic Erwinia, Pantoea and Enterobacter strains including type strain of each species and the four strains pathogenic to Pyrus pyrifolia that were characterized by using Biotype 100 strips and 22 additional tests. The Asian pear 
pathogen constituted the phenon 1, which was closely related but distinct from Erwinia amylovora. Since these strains constitute a close DNA group that can be identified by using phenotypic tests, we propose that this new phytopathogenic organism should be recognized as a new species, Erwinia pyrifoliae sp. nov.

\section{Description of Erwinia pyrifoliae sp. nov.}

Erwinia pyrifoliae (py.ri.fo'liae. L. gen. fem. n. pyrifoliae of pyrifolia, the species name of the host plant, the Nashi pear, Pyrus pyrifolia).

Cells are Gram-negative, non-spore-forming, peritrichous, straight rods. The strains are facultatively anaerobic, oxidase is not produced. Nitrates are not reduced. The species conforms to the definition of the family Enterobacteriaceae. Strains grow on YPDA medium, producing colonies that are $2 \mathrm{~mm}$ after $48 \mathrm{~h}$ at $28{ }^{\circ} \mathrm{C}$. Colonies are circular white, well-domed and opaque. Glucose (dextrose) is fermented without gas production. Voges-Proskauer test is (weakly) positive. Polypectate gel is not acidified or liquefied. Arginine dihydrolase, lysin decarboxylase and ornithine decarboxylase are not present. Indole is not produced from tryptophan. RCS are produced. Acid is not produced from inulin, lactose, methyl $\alpha$-glucoside, melibiose, D-arabitol, D-arabinose or raffinose. Acid is produced from mannitol, sorbitol, saccharose. There is no alkalinization of malonate, citrate or D-tartrate. $\beta$-Galactosidase is not produced. The following substrates are utilized as sole sources of carbon and energy: D-fructose, D-galactose, D-trehalose, saccharose, methyl D-glucopyranoside, D-ribose, L-arabinose, glycerol, myo-inositol, D-mannitol, D-sorbitol, Lmalate, $N$-acetyl-D-glucosamine, D-gluconate, succinate, fumarate, L-glutamate, L-proline. The following substances are not utilized: D-mannose, D-sorbose, $\alpha$-D-melibiose, D-raffinose, maltotriose, maltose, $\alpha$-lactose, lactulose, methyl $\beta$-galactopyranoside, D-cellobiose, $\beta$-gentiobiose, aesculin, $\mathrm{D}$-xylose, palatinose, $\alpha$-L-rhamnose, $\alpha$-L-fructose, D-melibiose, D-arabitol, L-arabitol, xylitol, dulitol, D-tagatose, maltitol, D-turanose, adonitol, hydroxyquinoline $\beta$-glucuroside, 3-methyl D-glucopyranoside, $\mathrm{D}$-saccharate, mucate, L-tartrate, D-tatrate, mesotartrate, D-malate, trans-aconitate, tricarballylate, D-glucuronate, D-galacturonate, keto-D-gluconate, L-tryptophan, phenylacetate, protocatechuate, $p$ hydroxybenzoate, quinate, $\mathrm{m}$-hydroxybenzoate, benzoate, phenylpropionate, m-coumarate, trigonelline, betaine, putrescine, aminobutyrate, histamine, DLlactate, caprate, caprylate, L-histidine, glutarate, DLglycerate, aminovalerate, ethanolamine, tryptamine, itaconate, hydroxybutyrate, D-alanine, malonate, propionate, L-tyrosine, ketoglutarate.

The pathogen was isolated from necrotic symptoms of leaves and branches of Pyrus pyrifolia cv. 'Shingo'. It is closely related to the fire blight pathogen Erwinia amylovora for the DNA sequence of the 16S rDNA, but distantly for its intergenic transcribed spacer region (ITS). It does not contain plasmid pEA29 (Rhim et al., 1999). The $\mathrm{G}+\mathrm{C}$ content of the genomic DNA is $52 \mathrm{~mol} \%$. The type strain $\left(\right.$ Ep16/96 $\left.{ }^{\mathrm{T}}\right)$ has been deposited in the Collection Française des Bactéries Phytopathogènes as CFBP $4172^{\mathrm{T}}$ and the Deutsche Sammlung von Mikroorganismen und Zellkulturen as DSM $12163^{\mathrm{T}}$. Additional strains deposited are Ep8/95 (= DSM 12393), Ep1/96 (= CFBP $4171=$ DSM 12162), Ep28/96 (= CFBP 4173), Ep31/96 (=CFBP 4174) and Ep4/97 (=DSM 12394).

\section{REFERENCES}

Ayers, S. H., Rupp, P. \& Johnson, T. (1919). A study of the alkaliforming bacteria. Milk. USDA Bulletin 782 .

Bereswill, S., Pahl, A., Bellemann, P., Zeller, W. \& Geider, K. (1992). Sensitive and species-specific detection of Erwinia amylovora by polymerase chain reaction-analysis. Appl Environ Microbiol 58, 3522-3526.

Bereswill, S., Bugert, P., Bruchmüller, I. \& Geider, K. (1995). Identification of Erwinia amylovora by PCR with chromosomal DNA. Appl Environ Microbiol 61, 2636-2642.

Bereswill, S., Jock, S., Bellemann, P. \& Geider, K. (1997). Identification of Erwinia amylovora by growth in the presence of copper sulfate and by capsule staining with lectin. Plant Dis $\mathbf{8 2}$, 158-164.

Brenner, D. J., McWorter, A. C., Leete Knutson, J. K. \& Steigerwalt, A. G. (1982). Escherichia vulneris: a new species of Enterobacteriaceae associated with human wounds. $J$ Clin Microbiol 15, 1133-1140.

Chung, Y. R., Brenner, D. J., Steigerwalt, A. G., Kim, B. S., Kim, H. T.\&Cho, K. Y. (1993). Enterobacter pyrinus sp. nov. an organism associated with brown leaf spot disease of pear trees. Int J Syst Bacteriol 43, 157-161.

Crosa, J. M., Brenner, D. J. \& Falkow, S. (1973). Use of a singlestrand-specific nuclease for analysis of bacterial and plasmid deoxyribonucleic acid homo- and heteroduplexes. $J$ Bacteriol 115, 904-911.

Falkenstein, H., Bellemann, P., Walter, S., Zeller, W. \& Geider, K. (1988). Identification of Erwinia amylovora, the fireblight pathogen, by colony hybridization with DNA from plasmid pEA29. Appl Environ Microbiol 54, 2798-2802.

Kwon, S.-W., Go, S.-J., Kang, H.-W., Ryu, J.-C. \& Jo, J.-K. (1997). Phylogenetic analysis of Erwinia species based on 16S rRNA gene sequences. Int J Syst Bacteriol 47, 1061-1067.

Leblond-Bourget, N., Philippe, H., Mangin, I. \& Decaris, B. (1996). $16 \mathrm{~S}$ rRNA and $16 \mathrm{~S}$ to $23 \mathrm{~S}$ internal transcribed spacer sequence analysis reveal inter- and intraspecific Bifidobacterium phylogeny. Int J Syst Bacteriol 46, 102-111.

Lelliott, R. A. \& Stead, D. E. (1987). Methods for the Diagnosis of Bacterial Diseases of Plants. Oxford: Blackwell.

Loughney, K., Lund, E. \& Dahlberg, J. E. (1982). tRNA genes are found between $16 \mathrm{~S}$ and 23S rRNA genes in the Bacillus subtilis. Nucleic Acids Res 10, 1607-1624.

Marmur, J. \& Doty, P. (1962). Determination of the base composition of deoxyribonucleic acid from its thermal denaturation temperature. $J$ Mol Biol 5, 109-118.

Owen, R. J. \& Lapage, S. P. (1976). The thermal denaturation of partly purified bacterial deoxyribonucleic acid and its taxonomic implications. J Appl Bacteriol 41, 335-340. 